\title{
Breeding possibilities of Booroola Merino in East-Europe
}

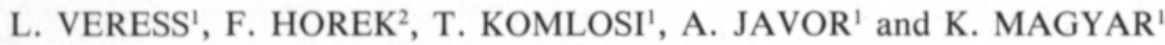 \\ 'University of Agriculture, Debrecen, Hungary \\ ${ }^{2}$ University of Agriculture, Brno, Czechoslovakia
}

\begin{abstract}
Booroola Merino (BM) rams and ewes were imported from New Zealand to Hungary and Czechoslovakia in the 1980's. Part of the imported animals were proved to be homozygous for the F gene. Frozen semen of these has been used for spreading this gene to Hungarian (HM) and Czechish (CM) Merinos. The crossbred lambs were 4-7\% lighter at birth and at $30 \mathrm{~d} ., 6-24 \%$ lighter at $100 \mathrm{~d}$. and 5-10 \% lighter at 1-yr than $\mathrm{HM}$. The 1-yr weight was $10-22 \%$ lighter than that of CM. Greasy fleece weights were 5-10 \% higher, staple lengths $7-11 \%$ longer than in $\mathrm{HM}$ or $\mathrm{CM}$, while fibres were finer. The litter size of $\mathrm{BM} \times \mathrm{HM}$ ewes at 1st lambing was 1.42 , at 2 nd 1.52 and at 3 rd 1.69 , while the last figure for $\mathrm{HM}$ ewes was 1.15 . The $\%$ of twins born to the $\mathrm{BM} \times \mathrm{HM}$ ewes was ca. $35 \%$, when $\mathrm{HM}$ ewes had $12 \%$. The corresponding figures for triplets were 9 and $0.2 \%$. The $\mathrm{BM} \times \mathrm{HM}$ crosses had shorter anestrus periods after lambing than $\mathrm{HM}$ ewes, except after the first lambing. The $\mathrm{BM} \times \mathrm{HM}$ ewes produced $2.4 \mathrm{lambs} / \mathrm{yr}$. in a continuous lambing system, while $\mathrm{HM}$ ewes gave 1.9 lambs.
\end{abstract}

Index words: Booroola, Merino, Hungarian Merino, Czechish Merino, crossbreeding, live weight, fleece weight, litter size, lambing interval

\section{Introduction}

By breeding strains viz. Elektoral in Germany, Negretti in Bohemia and in Hungary, and Mazajevi in Russia, these countries played a significant role in Merino (M) breeding in the third part of the $19^{\text {th }}$ century in Europe. Nowadays, most Ms in the East-European countries are bred in Germany and the G.D.R., Hungary and in the Soviet Union, where primarily meat, meat + fleece and fleece + meat producing strains, respectively, are kept, while in other countries such as Czechoslovakia, Poland, Rumania and Bulgaria fleece + meat producing strains are dominant. In Hungary, Rumania and Bulgaria some of the Ms are milked as well. Since 1968, accelerated lambing has shown a rapid increase in Hungary (14).

For the past decades an increase in mature body weight has become general in almost every strain of M. Although the direct and com- 
binative crossing for production of $\mathrm{M}$ has yielded promising results $(5,9)$, it has failed to become prevalent in large-scale sheep farming.

In England, for the last decades, pure breeding has been reduced to the indispensable reproductional ratio, giving way to a wide range of combinative productional crossing. In comparison with the pure breeding of meat producing strains, this sort of crossing has proved to be far more productive and economical (16).

Booroola Merino (BM) is likely to prove an excellent partner for crossing in those regions of East Europe that are suitable for breeding M (13, 15). Therefore we wish to highlight here some of our plans pertaining to the utilization of this breed.

\section{Subject and method}

In response to our recommendation, 20 rams and 3 ewes were brought from Haldon Station, New-Zealand (N.Z.), in the years of 1980, 1982 and 1986, to enlarge the available experimental stock. In 1985, Czechoslovakia bought 7 rams from the same source. This stock was the offspring of 19 rams altogether which descended from 9 original rams imported from Robertson's stock in Australia. While still in N.Z., four of them were qualified as homozygotes on the $\mathrm{F}$ gene, five other sires were either not assessed or were labelled as heterozygotes. Our intention is to promote Fgene homozygote populations in several breeding stocks, which could then subsequently be developed into nucleus.

Besides focusing on producing F-gene homozygous stocks, we endeavour to improve maternal traits (i.e. oestrus aseasonality, perfect conceiving and lamb rearing capability) as well as the parameters of fleece producing capacity (i.e. clean-fleece yield, ratio of fine and long staples).

For the purpose of achieving this, the sperm of the best imported rams has been frozen so that "post mortem" fertilization could be carried out. The sperm of heterozygous rams is going to be used only when a sufficient number of homozygous ewes are available so that homozygous lines could be obtained from them, as it is done in N.Z. and France as well $(4,8)$. Mating heterozygous partners is also preferable because, on the one hand, 1/4 of the offspring is homozygous, and their phenotype is closer to that of Hungarian M (HM), on the other hand, the gene frequency of the breed is extended as well. The deep-frozen sperm is introduced into the uterine horn by means of an endoscope. The fertility rate, however, has not exceeded the $30-40$ percent level and it is still far from the results of $60 \%$ reported by Salamon et al. (11).

Parallel with new-breed crossing threebreed crossing has also been initiated where partner A is HM on Czech $\mathbf{M}$ and partner B is a BM, an the terminal partner is a Suffolk which, owing to its high growth capacity, compensates for the lower growth rate of the $\mathrm{BM}$, and moreover it contributes to improving meat ratio and feed conversion.

There is no doubt, that ewes obtained from this crossing are smaller in weight, but this is not considered to be a shortcoming. Their phenotype, however, is the same as that of $\mathrm{HM}$, their relative fleece production is more favourable. Moreover, this sort of fleece can be marketed at a $20 \%$ higher price as it is finer, longer stapled and cleaner as well (15).

\section{Achieved results}

The body weight of the imported rams alternated between $50-70 \mathrm{~kg}$. Due to indoor breeding it has increased by $30 \%$, the fibre diameter has become 3 microns coarser, staple length and rendement have remained constant while clean fleece yield has increased by $5 \%$ (7).

The lambs of imported BM rams weigh $4-7 \%$ less, at the age of 30 days they lag behind by $5-7 \%$ and when they were 100 days old they weighed $6-24 \%$ less than the HM (15). When they were one year old, their weight decreased by 5-10\% in Hungary and by $10-22 \%$ in Czechoslovakia in compari- 
son with pure bred control animals. Grease fleece yield decreased by $1-18 \%$ in Hungary and by $10-22 \%$ in Czechoslovakia.

Grease fleece production in relation to the control group increased by $5-10 \%$ together with the increase of staple length $(7-11 \%)$, whilst fur became finer and the rendement improved $(6,14)$. The influence of BM crossings on decreasing growth and mature body weight has been pointed out by several authors (4). It has also been reported that this effect is of the same degree in both F-gene-bearing homozygous and heterozygous rams (11).

This is true in respect of slaughtering and fleece production characteristics as well (6).

We are firmly convinced that the variance in mature body weight is partly of phenotypic origin which is caused, on one hand, by prenatal and postnatal state of nourishment and, on the other hand, by the age when the animals are used for breeding. Our observations indicate that the $\mathrm{BM}$ can be classified as a slowly developing and growing type. Despite this fact a bigger genotype could be produced, if it were so desired.

Sperms from 15 homozygous and 4 presumably heterozygous rams originating from 6 lines have been frozen so far. We have to store sperm of 10 rams from two further lines.

Fecundity results seem to be satisfactory, though, 3 of the rams that could be appraised so far are merely heterozygous carriers of the F gene. The first lambings happened when the ewes were on the average of $21-22$ months old (15), but in spite of this the rate of twinnings amounted to $30-37 \%$, the frequency of litters with 3 lambs alternated between 3 and $13 \%$. In the course of the second and third lambings this rate grew by an additional $10 \%$. In comparison with $\mathrm{AM}$ ewes with repeated lambings, the rate of productivity was $54 \%$ better.

Ewes are lambing continually on the farm from which these data are obtained. Thus it

Table 1. Progeny test of 4 rams for their daughters' prolificacy.

\begin{tabular}{|c|c|c|c|c|c|c|}
\hline \multirow[t]{2}{*}{ Rams } & \multirow{2}{*}{$\begin{array}{c}\text { lambing } \\
\text { n }\end{array}$} & \multirow{2}{*}{$\begin{array}{c}\text { lambing } \\
\text { rate } \\
\%\end{array}$} & \multicolumn{2}{|c|}{ twins } & \multicolumn{2}{|c|}{ triplets and more } \\
\hline & & & $\mathbf{n}$ & $\%$ & $\mathbf{n}$ & $\%$ \\
\hline \multicolumn{7}{|c|}{ first } \\
\hline $502 / 78$ & 162 & 145,0 & 61 & 37,6 & 6 & 3,0 \\
\hline $62 / 80$ & 119 & 140,0 & 39 & 32,8 & 6 & 5,0 \\
\hline $51 / 80$ & 222 & 138,0 & 74 & 33,3 & 6 & 2,7 \\
\hline $183 / 80$ & 15 & 206,6 & 5 & 30,0 & 2 & 13,3 \\
\hline$\Sigma x$, or $\bar{x}$ & 518 & 142,0 & 179 & 34,5 & 20 & 3,86 \\
\hline \multicolumn{7}{|c|}{ se c o n d } \\
\hline $502 / 78$ & 147 & 158,0 & 57 & 38,7 & 13 & 8,0 \\
\hline $62 / 80$ & 95 & 168,0 & 38 & 40,0 & 13 & 13,8 \\
\hline $51 / 80$ & 191 & 153,0 & 57 & 29,8 & 22 & 11,4 \\
\hline $183 / 80$ & - & - & - & - & - & - \\
\hline$\sum x$, or $\bar{x}$ & 433 & 152,0 & 152 & 35,1 & 48 & 11,0 \\
\hline \multicolumn{7}{|c|}{$\mathrm{th} \mathrm{ird}$} \\
\hline $502 / 78$ & 71 & 163,0 & 30 & 42,2 & 7 & 9,4 \\
\hline $62 / 80$ & 51 & 182,0 & 16 & 31,1 & 13 & 25,5 \\
\hline $51 / 80$ & 111 & 166,0 & 38 & 34,2 & 17 & 16,2 \\
\hline $183 / 80$ & - & - & - & - & - & - \\
\hline$\sum x$, or $\bar{x}$ & 233 & 169,0 & 84 & 36,0 & 37 & 15,8 \\
\hline Hungarian & & & & & & \\
\hline $\begin{array}{l}\text { Merino } \\
\text { (control) }\end{array}$ & 451 & 114,5 & 56 & 12,4 & 1 & 0,2 \\
\hline
\end{tabular}




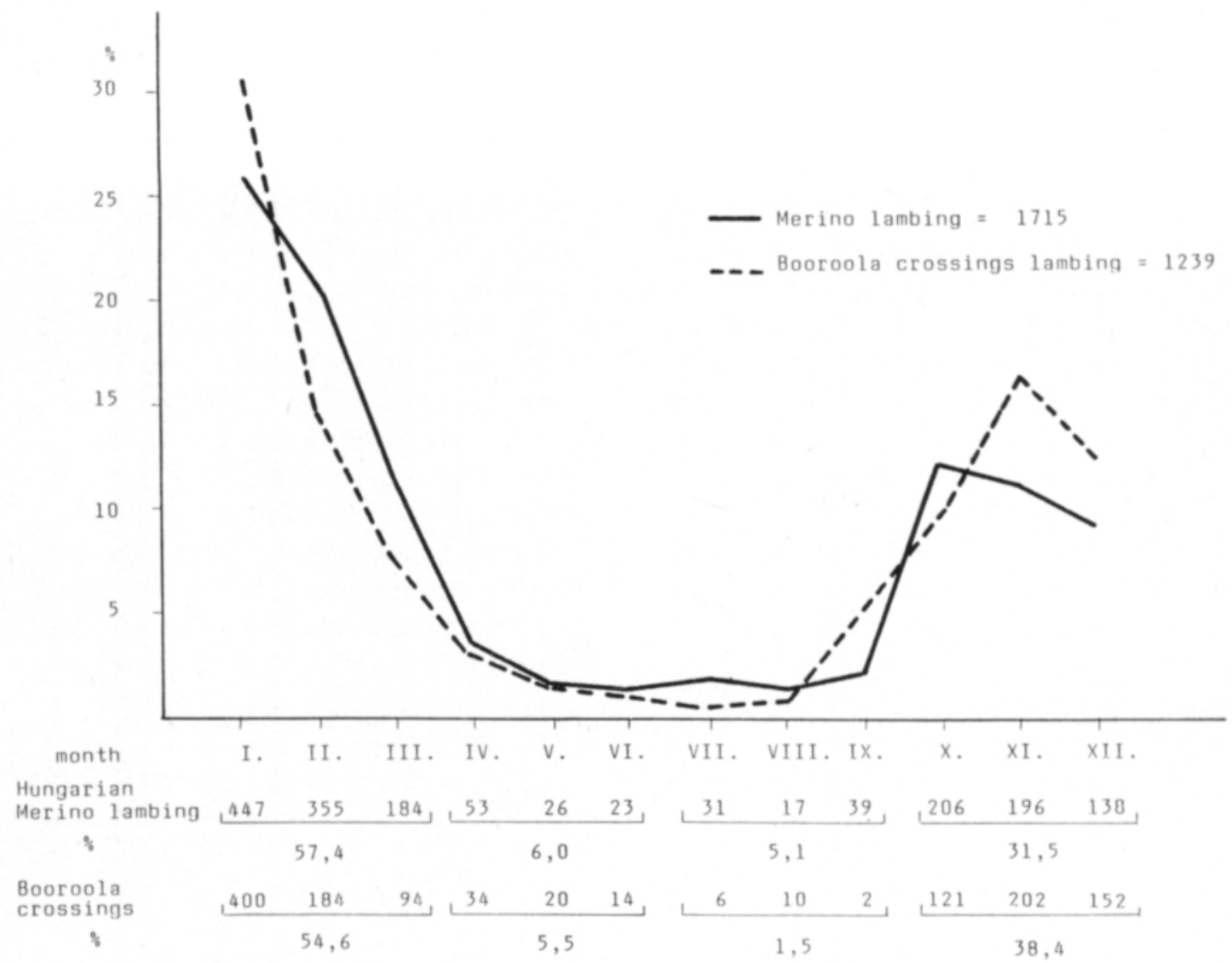

Fig. 1. The distribution of lambings per month of Hungarian Merinos and Booroolas on one farm in 1987.

has become possible to compare the abilities to accelereted lambing of HM and BM crossings (Table 1). The anoestrus period of the BM is a bit shorter than that of the HM as it is referred to in previous studies $(1,2)$. Significant difference was found between the average interval of the second and third lambing of BM crossings as far as the main season is concerned $(\mathrm{P}<1 \%)$, and in the pre-and postseasons as well as out-of-season $(\mathrm{P}<0,1 \%)$. The re-lambing interval of $\mathrm{M}$ used for control was naturally more favourable, since there was a disparity of $54 \%$ in the rate of reproduction, that made the recovery period necessary for the re-cycling of the F-gene heterozygote carrier ewes longer. Nevertheless, considering the average interval between the 2nd and 3rd lambings a significant difference was found to be advantageous for BM crossings $(\mathrm{P}<0,1 \%)$.
The distribution of the monthly lambings of $\mathrm{M}$ and $\mathrm{BM}$ crossings on the same farm in 1987 is shown in Figure 1.

The distribution is were even regarding lambings of $\mathrm{M}$ in periods of a quarter of a year. While the average lambings of the $\mathrm{M}$ was 1.9 for 1987 , in the case of the BM crossings this value came to 2.4 .

Currently the most difficult long-lasting technological task is to increase the vitality of the born lambs and to keep them alive.

Dyrmundsson and Adalsteinsson (3) pointed out that concerning Icelandic sheep there is a definite relationship between the pigmentation of the fur and fecundity capabilities. Pigment spots on the face and on the end of the legs were found more frequent in the case of the Hungarian daughters of BM rams than in that of Hungarian M. 
Table 2. The relambing interval of Hungarian Merino and heterozygote $(F+)$ Booroola crossings depending on the conceiving time.

\begin{tabular}{|c|c|c|c|c|c|c|c|c|c|}
\hline \multirow[t]{2}{*}{$\begin{array}{l}\text { Conceiving } \\
\text { time }\end{array}$} & & \multicolumn{2}{|c|}{$\begin{array}{l}\text { Main season } \\
(1.9-30.11)\end{array}$} & \multicolumn{2}{|c|}{$\begin{array}{c}\text { Pre-post-season } \\
(1.12-31.1)(1.7-31.8)\end{array}$} & \multicolumn{2}{|c|}{$\begin{array}{l}\text { Out of season } \\
(1.2-30.6)\end{array}$} & \multicolumn{2}{|c|}{ Total } \\
\hline & & $\begin{array}{c}\mathrm{HM} \\
\text { (control) }\end{array}$ & $\begin{array}{c}\mathrm{BM} \\
(\mathrm{F}+)\end{array}$ & $\begin{array}{c}\text { HM } \\
\text { (control) }\end{array}$ & $\begin{array}{c}\mathrm{BM} \\
(\mathrm{F}+)\end{array}$ & $\begin{array}{c}\text { HM } \\
\text { (control) }\end{array}$ & $\begin{array}{c}\mathrm{BM} \\
(\mathrm{F}+)\end{array}$ & $\begin{array}{c}\text { HM } \\
\text { (control) }\end{array}$ & $\begin{array}{c}\mathrm{BM} \\
(\mathrm{F}+)\end{array}$ \\
\hline \multirow{4}{*}{$\begin{array}{l}\text { first- } \\
\text { second }\end{array}$} & $\mathbf{n}$ & 26 & 53 & 10 & 180 & 8 & 39 & 44 & 272 \\
\hline & $\bar{x}$ & 351 & 323 & 294 & 353 & 324 & 404 & 333 & 354 \\
\hline & s & 111 & 86 & 111 & 93 & 119 & 92 & 115 & 91 \\
\hline & CV\% & 31.5 & 26.9 & 37.6 & 26.4 & 36.7 & 22.8 & 34.4 & 38.7 \\
\hline \multirow{4}{*}{$\begin{array}{l}\text { second- } \\
\text { third }\end{array}$} & $\mathrm{n}$ & 6 & 32 & 119 & 88 & 155 & 12 & 280 & 132 \\
\hline & $\bar{x}$ & 363 & 292 & 331 & 302 & 293 & 285 & 310 & 298 \\
\hline & s & 136 & 45 & 94 & 41 & 97 & 105 & 99 & 50 \\
\hline & CV\% & 37.4 & 15.3 & 28.5 & 13.5 & 33.2 & 36.9 & 31.9 & 59.3 \\
\hline \multirow[t]{4}{*}{ total } & $\mathrm{n}$ & 32 & 85 & 129 & 268 & 163 & 51 & 324 & 404 \\
\hline & $\bar{x}$ & 353 & 311 & 328 & 333 & 294 & 376 & 313 & 336 \\
\hline & s & 113 & 75 & 95 & 85 & 98 & 107 & 101 & 80 \\
\hline & $\mathrm{CV} \%$ & 31.1 & 24.1 & 34.6 & 25.4 & 30.1 & 28.5 & 30.9 & 41.8 \\
\hline
\end{tabular}

\section{Conclusions}

Specific yields can be increased significantly in East-European territories suitable for Merino (M) keeping by means of crossing first with Booroola (BM) rams and with Suffolk used as terminal partners in comparison with fleece, meat and meat-fleece producing strains of the M. On a Hungarian farm with 3,000 ewes, where continual lambing goes on throughout the year, ewes crossed with BM obtained a productivity rate of $142 \%$ for the first lambing, $152 \%$ for the second and $169 \%$ for the third one. $M$ ewes lambing more than three times produced a productivity rate of $114,5 \%$.

$\mathrm{BM}$ crossed ewes pregnant for the first time conceived again later than Hungarian, but their following interval of re-lambing on the average was more favourable than that of Hungarian M. This deviation is sustained statistically $(\mathrm{P}<0.1 \%)$. As regards fecundity data, BM crossings are inevitably better; in 1987, against the background of 2,000 M ewes, the annual value of annual increase came to 1.9 , while for 1000 crossed ewes this indicator was found 2.4 lambs.

\section{References}

1. Bindon B.M., Piper, L.R. \& Evans, R., 1982. Reproductive Biology of the Booroola Merino. Proc. Worksh. at Armidale NSW. Aug. Div. of. Anim. Prod., CSIRO, Austr.

2. Bindon, B.M., 1984. Reproductive biology of the Booroola Merino Sheep. Austr. J. Biol. Sci. 37. 163-189. p.

3. Dyrmundsson, O.R. \& Adalsteinsson, S. 1980. Coat colour supresses sexuale activity in Icelandic sheep. J. Heredity 71: 363.

4. Elsen, J.M. \& Ortavant, R., 1984. Le gene Booroola mise en evidence functionnement perspectives d'utilisation. 9-ième Journ. Rech. Ovine et Capr. (Paris) INRA-ITOVIC: 415-451.

5. GOHler, H., 1978. Unterzuchungen zur Bestimmung der Körperentwicklung und des Schlahtkörperwertes bei Lämmern. Diss. B. K.-M. Univ. Leipzig.

6. Hinch, G.N., Kelly, R.W., Davis, G.H. Owens, J.L. \& CRosbie, S.T. 1985. Factors affecting lambs birth weights from high fecundity Booroola ewes. Anim. Repr. Sci. Amsterdam. 8.1/2 53-60. p.

7. Horak, F., 1987. Ergebnisse aus der Zucht der Booroola Schafe in der Tschechoslowach. Sozialist. Republik. Wiss. Tag. Humbold Univ. 3-4. Dez. Berlin.

8. Kleemann, D.O., Ponzoni, R.W., Stafford, J.E., Cutten, I.N. \& Crimson, R.Y., 1985. Growth and 
carcass characters of the South Australian Merino and its Crosses with the Boorola and Tharghee fertility Merino. Austr. J. Exp. Agric., Melbourne. 25. 4: 750-757. p.

9. Kelly, R.W., Davis, G.H. \& Alluson, A.J., 1982. Productive changes in longwool breeds in New Zealand following crossbreeding with Booroola type rams. Proc. Austr. Soc. Anim. prod. CSIRO. Armidale 13. 413-416.

10. Könı, K.H., 1978. Möglichkeiten zur Verbesserung der Fortpflanzungsleistung weiblicher Schafe durch Massnahmen der Züchtung und durch gesteuerte Tageslichtlängen. Diss. B. K.-M. Univ. Leipzig.

11. Ponzoni, R.W., Fleet, N.R., Walkley, I.R.W. \& WALKER, R.K., 1985. A note on the effect of the F gene on wool production and live weight of Booroola $X$ South Australian Merino rams. Anim. Prod. 40: 367-369. p.

12. Salamon, St., Maxwell, W.M.C. \& Evans, G.,
1985. Fertility of ram semen frozen-stored for 16 years. Proc. 7.th. Annual Conf. Austr. Repr. Biology. Adelaide 62. p.

13. Veress, L., 1983. Adatok a booroola merino tenyésztési programjához.

14. Veress, L., Végh, J., Turai, I., Tarnóczi, T. \& ECSEDY, J., 1987. Some conclusions concering the large-scale accelerated lambing of Hungarian Merino ewes. Acta Agr. Hung. Budapest. 37./1-2/ 111-121. p.

15. Veress, L. \& Aluison, A.J. 1988. Improvement of Merino sheep for profilicacy. Acta Agr. Hung. Budapest. 37./1-2/ 173-182. p.

16. Wassmuth, R., 1971. Optimale Verwendung des genetischen Materials unter spezieller Berücksichtigung der Kreuzung im Vergleich zu anderen Zuchtverfahren. Schafe und Ziegen. X. Intern. Tierzucht Kongr. Paris, Versailles: 97-115. p. 